\title{
How do Candidate Science Teachers Solve Environmental Problems? ${ }^{1}$
}

\section{OPEN ACCESS}

Manuscript ID:

EDU-2021-09044143

Volume: 9

Issue: 4

Month: September

Year: 2021

P-ISSN: 2320-2653

E-ISSN: 2582-1334

Received: 22.06.2021

Accepted: 24.07.2021

Published: 01.09.2021

Citation:

Berber, Asiye. "How Do

Candidate Science Teachers

Solve Environmental

Problems?" Shanlax

International Journal of

Education, vol. 9, no. 4,

2021, pp. 247-58.

DOI:

https://doi.org/10.34293/

education.v9i4.4143

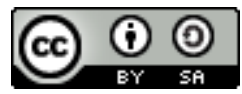

This work is licensed under a Creative Commons Attribution-ShareAlike 4.0 International License

\author{
Asiye Berber \\ Assistant Professor, Faculty of Education, Eskişehir Osmangazi University, Eskişehir, Turkey \\ https://orcid.org/0000-0002-8340-4793
}

\begin{abstract}
The aim of this study is to determine the views of candidate science teachers about environmental problems and solutions to these problems. One of the qualitative research designs, phenomenology, was used in the research. Data were collected with a semi-structured interview form developed by the researcher. In the analysis of the research, a descriptive analysis technique was used. The study was carried out with 19 science teacher candidates. When definitions of the environment are examined, it is as "the environment in which living and non-living beings interact, the area where living things live, the artificial environment-natural environment." Candidate teachers identified air pollution as the most important environmental problem. They stated that environmental problems occur due to production, consumption, both production and consumption and natural reasons. Candidate teachers discussed solution proposals of environmental problems individually, professionally, socially, and administratively. In individual solution proposals, it is recommended to use public transport, to encourage afforestation, to consume resources economically, to reduce the use of perfume-deodorants and fossil fuels, and to raise awareness with experiments, activities, visual and practical solutions under professional solution suggestions. When social solution suggestions are examined, it is stated that to raise awareness; it is necessary to produce visual and artistic activities, meetings, training, and projects, to be engaged in conscious agriculture in managerial solution offers, to use renewable energy sources, to recycle, to build industrial establishments outside of residential areas, to establish treatment facilities, and to install and inspect filters in factory chimneys.
\end{abstract}

Keywords: Candidate teacher, Environmental problems, Science, Solution suggestions.

\section{Introduction}

Environmental problems appear with damage to the environment, which occurs as environmental degradation or pollution while meeting various needs of human beings. Environmental problems like climate change, global warming, greenhouse effect, carbon footprint, garbage, melting of glaciers, acid rain, air pollution, water pollution, soil pollution arise for various reasons (Brody, 1991, Kim, Harish, Kennedy, Jin, \& Urpelainen, 2020; Soares, Miguel, Venâncio, Lopes, \& Oliveira, 2021; Yoloğlu \& Halisdemir, 2020). Different solutions are offered for the elimination of environmental problems. Jorgenson, Stephens and White (2019) recommended that environmental educators and researchers act together and that a vision and strategy on climate change and energy education be adopted. To eliminate these problems, awareness studies, public service announcements, actions are carried out and solutions are sought. Educating people about environmental issues is vital for sustainability and for developing a societal foundation. (Toomey and Domroese, 2013). Environmental education has an increasing significance in the awareness and solution process of environmental problems. (Özdemir, 2007; Karadağ, 2020). Environmental education is important in terms of raising individuals who are environmentally sensitive and can offer solutions to environmental problems.

1. This study was presented as an oral presentation of the conference "VIIIth International Eurasian Educational Research Congress" 
In this context, education faculties are the most important institutions where teachers primarily gain knowledge, skills, and perspectives on environmental problems. (Farsakoğlu, Şahin, Karslı, Akpınar \& Ultay, 2008). Environmental education that is to be given to children might have two purposes: first, to provide children with a cultural accumulation; the second is to give information about the environment, environmental problems, and the solution of those problems (Morgil, 2002). Akman (2017) stated in his research that the reason behind the environmental knowledge and the interest in environmental problems of the students studying in primary school teaching and social studies teaching can be explained as a result of taking an "environmental education" course and that individuals with a high level of education do not hesitate to take responsibility for the solutions of environmental problems. Additionally, some studies suggest that university students should take environmental courses as compulsory. (AlMaliki, Farhan, Jasim, Al-Mamoori, \& Al-Ansari, 2021). By providing environmental education at the university, it can be ensured that students become environmentally literate and acquire environmentalist behaviors (Lloyd $\square$ Strovas, Moseley, \& Arsuffi., 2018). In this context, examining candidate science teachers' views and awareness of environmental problems will enable candidate teachers to create and develop solutions for environmental problems and determine the current situation.

In this study, the aim is to determine the views of candidate science teachers about environmental problems and solutions to these problems. The research sought answers to the following sub-problems:

Science teacher candidates;

1. How do they define the environment?

2. What is the most important environmental problem they identified?

3. What are their views on the causes of environmental problems?

4. What are their solution suggestions to environmental problems?

5. What are their self-evaluations about the environment?

\section{Method}

\section{Data Collection Tools}

Phenomenology, one of the qualitative research designs, was used in the research. Since the main data collection tool used in phenomenology research is an interview (Yıldırım \& Şimşek, 2013), a semi-structured interview form developed by the researcher was used to collect data in this study. The interview is a data collection tool in which two people participate, and in-depth, rich information is obtained (Bogdan \& Biklen, 2006; McMillian, 2004). The semi-structured interview form was prepared by reviewing the relevant literature and taking the opinions of field experts. The interview form developed by the researcher was applied after the arrangements were made in line with the opinions of six field education experts. In the research, first, questions to determine the personal characteristics of the participants and the composition data they wrote about the environment were collected via the internet. Afterward, the candidate teachers' writings on the subject of "environment" were examined and interviews were conducted on the internet. The interviews lasted between 22 and 55 minutes and were recorded. The research was carried out with 19 science teacher candidates, 17 female and 2 male, studying at a state university and taking the same elective course. The participants of the study were selected by the easily accessible case sampling method, one of the purposive sampling methods.

\section{Analysis of Data}

Descriptive analysis technique was used in the analysis of the research. The main questions in the semi-structured interview form prepared for collecting research data were accepted as the theme. Opinions were analyzed by giving a code to each of the participant teacher candidates $(\mathrm{S} 1, \mathrm{~S} 2, \ldots \ldots$, S19). To increase the validity and reliability of the study, participant confirmation was provided, and direct citations were made from participant views. The researcher who carried out the research created the sub-themes. An independent researcher who did not know about the research was also asked to place the views of randomly selected candidate teachers into appropriate themes. There was no difference between the themes created by the independent researcher and the themes created by the researchers. 


\section{Findings and Results}

As seen in figure 1, the research findings aiming to determine the solution suggestions of the candidate science teachers to environmental problems were examined under five main themes: the definition of the environment, the most important environmental problem, the causes of environmental problems, solution suggestions and their behavior towards the environment.

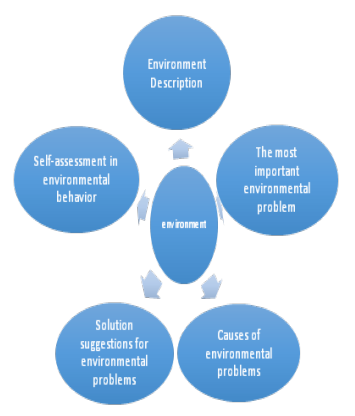

Figure 1: Candidate teachers' views on the environment and environmental problems

\section{Definition of Environment}

In the candidate teachers' writings and interviews on the environment, the environment was defined with many different sentences. When the definitions of the environment of the candidate teachers are examined, it is seen that they mostly describe the environment as "the environment where living and non-living beings interact (S7, S10, S11)" and "the area where living things live (S12, S13, S19)". Apart from these definitions, it is defined as "Artificial environment-natural environment (S1, S2, S3, S4, S5, S14)", "The structure interacting with humans (S9)", "The area including the entire universe (S7)". While defining the environment in general, it was also defined as "social environment (S5, S6, S8, S11)", stating that the definition of the physical and natural environment would be insufficient.

\section{The Most Important Environmental Problem}

After the interviews, candidate teachers determined the most important environmental problem, like air pollution. Based on the candidate teachers' statements, the most important environmental problem is given in the order of importance in figure 2.

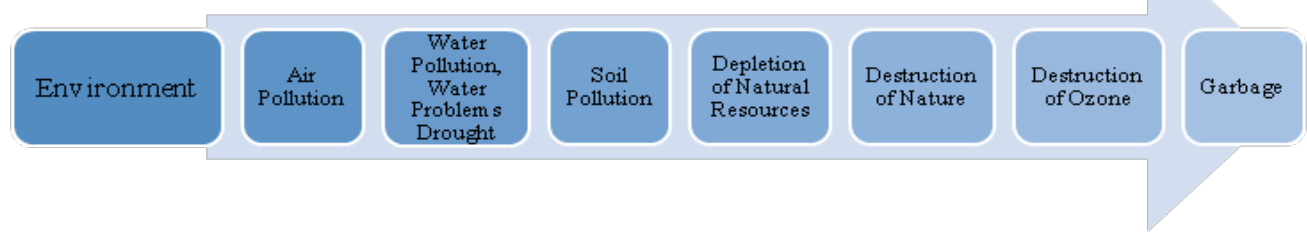

Figure 2: The most important environmental problems identified by candidate teachers

Candidate teachers stated that all environmental problems are important and trigger each other; although they had difficulty determining which one was the most important, they put them in order. "Air pollution" was indicated as the most important environmental problem. While candidate teachers were explaining the environment and environmental problems in general during the interview, they first talked about the environmental problems they experienced. They saw in their environment, and then explained the most important environmental problem they identified in general. It is observed that the most important environmental problem is the problems that the candidate teachers experienced, were affected by the environmental problems they saw and were also affected by the news. "Since the smoke coming out of the chimneys of the houses catches my eye, I can say that the most important problem is air pollution both in the place where I live and globally." (S3) can be given as an example.

Additionally, the reasons for choosing air pollution are the statements, "The less oxygen in the air, the harder it is for living things to breathe (S1, S4, S7, S15)". The fact that they were also affected 
by the news while identifying environmental problems is seen in the following statement: “...I read a news article that we would be dependent on oxygen tubes in the 2050s. Frankly, the thought of not being able to breathe terrifies me. (S17)". The candidate teachers rated the garbage thrown into nature, causing forest fires and harming nature, as the least important problem. The statement "The materials left to nature by people, which take many years to dissolve in nature, harm nature and the environment." (S8) explains the garbage problem.

\section{Causes of Environmental Problems}

In the research, when the opinions of the candidate teachers about the causes of environmental problems are examined, it is seen in figure 3 that they state that environmental problems occur due to production, consumption, both production and consumption and natural reasons.

\section{Causes of Environmental Problems}

\section{Froduction Oriented}

-Industrialization

-Factories

-Insensible agricultural practices

\section{Consumption Oriented}

- Fossil Fuels

- Vehicle-related

- Warming-induced

- Population Growth

- People Behaving Insensibly

- Cigarettes and Tobacco

- Perfume Deodorant

- Damaging Water Resources

- Damage to Forests

- Damage to Living Things

- No Recycling

-Drought, Desertification

\section{Both production and consumption oriented}

- Technological Developments

- Acid Rains

- Global Warming

- Greenhouse Gases

- Climate Change

Natural events

- Fire

- Flood

- Earthquake

- Sand Storm

- Volcanic Enuption

Figure 3: Causes of environmental problems 
Production Oriented Environmental Problems

As a result of the interviews with the teacher candidates, it is seen that industrialization, factories and insensible agricultural practices are environmental problems. These problems are included in the sub-theme of production-related problems. In the statements of the candidate teachers, it is seen that the industry and the factory pollute the environment with their wastes and gases while producing, which creates a problem. It is considered an environmental problem in "the increase of factories" (S1) statement. That the most basic point of production, farming, harms nature and the environment when done insensibly is shown in S5's statement as follows: "Agriculture-based insensible spraying, tree destruction and destruction of various living groups that benefit the soil can be counted." In general, it is stated that within the scope of insensible agricultural practices, the things that are done to increase production in agriculture, like spraying, burning stubble, and uncontrolled use of water, harm the environment.

\section{Consumption-Oriented Environmental Problems}

In the sub-theme of consumption-oriented problems, it is stated that the increase in the population means the increase in the needs of people and consumption. As a result, environmental problems occur. It is stated fact that people pollute water to meet their needs, consume fossil fuels for heating and transportation, waste natural resources, cut down trees for residential areas, destroy forests causes global warming, drought, and desertification. The sample opinions of candidate teachers are as follows, "Factors like cigarette smoke, bad fuel use, exhaust fumes from the factory chimneys, the use of perfumes and deodorants..." (S4) and "domestic wastes, industrial wastes, waste not suitable for recycling and trying to destroy these wastes in a way that may harm the environment...(S5).

\section{Environmental Problems, both Production and Consumption-Oriented}

In general, some problems occur both because of production and consumption. Greenhouse gases, acid rain, global warming, climate change and technology, which seem to result from production, are also part of consumption. "The technologization of our age, industrialization and factorization are among the biggest factors.... And the lack of their control, everything that people do with their own hands returns to them. The statement that follows explains that people produce and consume due to technology. Based on the general opinions of candidate teachers, factories, industrialization and production and emission of exhaust gases, use of deodorants and so on, cause greenhouse gases, global warming and with global warming climate change occurs. For example, the statement that follows explains that the causes of global warming are the results of production and consumption, "Fossil fuels, fumes from factory chimneys... ... Global warming is causing the ozone layer to be depleted. "(S18)

\section{Natural Events}

Teacher candidates state that natural causes like fires, floods, sandstorms, volcanic eruptions and earthquakes create environmental problems. The samples of teacher candidates' statements are, "Although factory fumes, fossil fuel use, stove use, vehicles, fires lit around are due to human use, fires, volcanic eruptions, acid rain, the dust created by sandstorms naturally pollute the air." (S2) and “...... natural or man-made fires, volcanic eruptions ....." (S7) 


\begin{tabular}{|c|}
\hline Solution Suggestions for Environmental Problems \\
\hline Individual solution suggestions \\
\hline $\begin{array}{l}\text { - Transportation } \\
\text { - Saving } \\
\text { - Heating } \\
\text { - Afforestation } \\
\text { - Reducing fossil fuel use } \\
\text { - Redusing the use of deodorant use }\end{array}$ \\
\hline Professional solution suggestions \\
\hline $\begin{array}{l}\text { - Raising awareness } \\
\text { - Explaining with experiments } \\
\text { - Establishing environmental clubs } \\
\text { - Installing taps with sensors } \\
\text { - Organizing nature/technical trips } \\
\text { - Organizing sapling planting activities }\end{array}$ \\
\hline Social solution suggestions \\
\hline $\begin{array}{l}\text { - Using social media to raise awareness } \\
\text { - Organizing public activities } \\
\text { - Organizing visual artistic activities } \\
\text { - Producing projects }\end{array}$ \\
\hline Managerial solution suggestions \\
\hline $\begin{array}{l}\text { - Giving importance to international agreements as a country } \\
\text { - Doing environmental controls and inspections } \\
\text { - The project of installing filters to factory chimneys } \\
\text { - Installing treatment facilities } \\
\text { - Cleaning seas, barrages, rivers } \\
\text { - Building industries away from cities } \\
\text { - Using sustainable energy resources } \\
\text { - Increaing the closeness and number of garbage cans } \\
\text { - Increaing the number of oil waste bins } \\
\text { - Burying garbage } \\
\text { - Recycling } \\
\text { - Limiting the smoking areas } \\
\text { - Raising awareness in agriculture }\end{array}$ \\
\hline
\end{tabular}

\section{Figure 4: Solution Offers of Teacher Candidates for Environmental Problems}

After the analysis of teacher candidates' statements, four sub-themes have been formed as individual, professional, social, and managerial (figure 4).

\section{Individual Solution Suggestions}

When individual solution suggestions are examined, the use of public transportation, promoting afforestation, saving resources, reducing the use of perfume-deodorant and fossil fuel are offered as solutions. The examples of individual solution suggestions are "... Increasing the use of bicycles will also be very useful." (S1), "We can use public transportation and apply thermal insulation to our homes" (S3) and "...we can plant saplings as a gift to our loved ones online. water treatment systems can be installed, reuse will save money." (S9)

\section{Professional Solution Suggestions}

While teacher candidates generally state individual, social and managerial solution suggestions, approximately half of them continued the interview saying, when I become a teacher (S3, $\mathrm{S} 5, \mathrm{~S} 6, \mathrm{~S} 9, \mathrm{~S} 12, \mathrm{~S} 14, \mathrm{~S} 15, \mathrm{~S} 19)$. This situation is also examined under the title of professional solution suggestions. In the interview, they stated that they wanted to make students aware of the extent of the damage done to the environment with experiments, activities, visual and practical purposes, and to realize the consequences of the problem that may 
arise from this damage, and that they wanted to work to decide on the solution process. Following statements can be presented as examples of learning by doing and experiencing with experiments, "If we ensure that the water is not used at school for a few days, they will understand its importance much better.”(S19) “....explaining the extent of the damage to the environment through various experiments and the consequences of the problem that may arise from this damage ..." (S6). Additionally, the example statements about drawing attention to the subject with different activities are, "we can use visualization techniques, organize various trips, encourage them to establish a club or suggest them to join"(S10). For practices, "Taps should be made with sensors so that we don't waste our water in our schools."(S12).

\section{Social Solution Suggestions}

When social solution proposals are examined, it is stated that it is necessary to raise awareness, meetings, training, and plan events and projects. Suggestions like advertisements, posters, social experiments, and public service announcements were made using social media for awareness-raising activities. For example, S14, "I would use social media. Because people of all ages are interested in social media, television and computers..." emphasized the importance of today's communication tools in raising awareness with this statement. There are solutions that suggest that organizing collective events will be more effective. Teacher candidates suggested that some social movements like Greenpeace, Green Deal, TEMA, Greta Thunberg be supported, and they emphasized that some environmental organizations should be increased. It is also recommended to carry out visual and artistic activities like social experiments, advertisements, films, posters, public service announcements, pictures, documentaries, cartoons, dramas, and theaters that are effective in raising awareness and to take social action by forming a unity. Teacher candidates express that state institutions and non-governmental organizations can play an important role in the solution process. They can organize training and activities and state that we should support them. The following statement can be given as an example, "....the training that will raise awareness should be given to all age groups by experts and well-equipped people on the subject."(S2). For example, institutions like the municipality, the ministry of forestry and TEMA have been included in the solution process. Teacher candidates suggest doing projects to solve environmental problems and showing the results with scenarios before the events happen.

\section{Managerial Solution Suggestions}

The managerial solution suggestions of the teacher candidates are the use of renewable energy sources, recycling, the establishment of treatment plants, conscious agriculture, filtering and inspection of factory chimneys, penalties for those who do not comply with the rules, and inspections and controls. Among the administrative solution proposals, the statement "International agreements including our country should be given more importance to these issues." (S7) is remarkable. In another example, a teacher candidate states how much the local government's environmentalist attitude with the public affects her and wants to work on these issues in the future. The lack of adequate recycling bins and trash cans presents some problems. Among the suggestions for solutions to these problems, "increasing the number of oil waste bins, placing garbage cans closely, burying garbage in pits" can be given as an example. To solve the problems caused by industrialization, teacher candidates suggested that the industry should be far from the city and residential areas. For example, experiencing the problem caused by the factory (S7) presented the following solution "Industrial places should be far away from the city." Teacher candidates stated that the water resources of the seas and rivers should not be polluted, and people should not litter. They also expressed different solutions when pollution occurs. During the interview, a teacher candidate stated that she saw a system that vacuums the garbage to clean seas in an advertisement and suggested solutions like "garbage ship, garbage taxi."

Additionally, the importance of sensible agriculture is emphasized. "Everyone who is engaged in agriculture should carry out their work under the leadership of an agricultural engineer and should receive support in matters like applying pesticide and fertilization" (S5). In another statement, the 
importance of "promoting the use of renewable make their self-evaluations about the environment. energy" (S7, S15, S18) was emphasized.

The data obtained from the interview are given in figure 5 in two sub-themes as positive and negative

Self-evaluation of Teacher Candidates' behaviors.

\section{Environmental Behavior}

In the study, teacher candidates were asked to

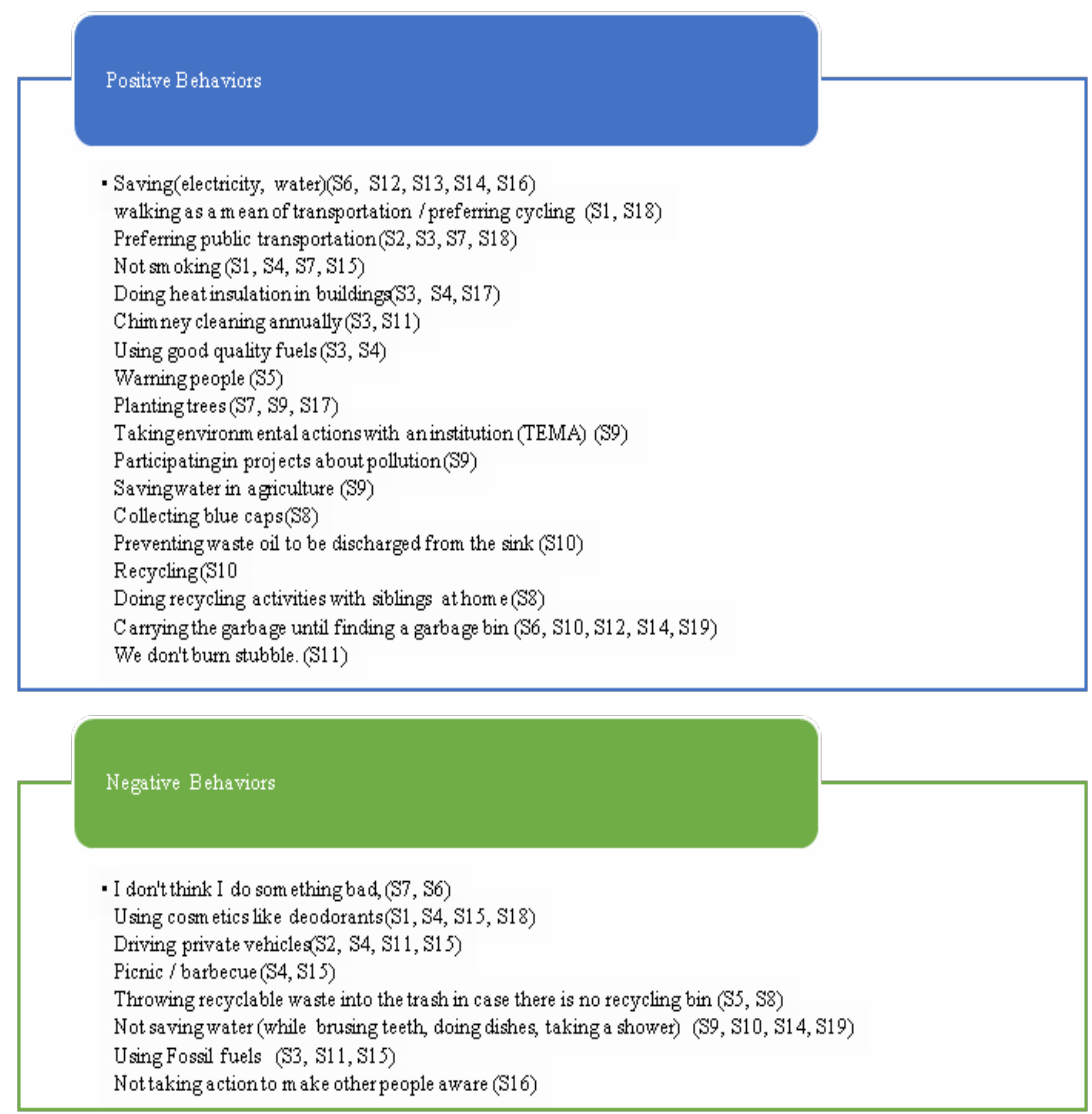

Figure 5: Self-evaluation in Behavior towards the Environment

Positive behaviors are more expressed in being economical, using public transport, throwing garbage in the trash, and not smoking. Additionally, differences like collecting and using rainwater as recycling, using recycling boxes properly, collecting blue caps, and doing recycling activities are expressed. A teacher candidate stated being a member of an organization and participating in environmental activities. They mostly state that they act carelessly about water-saving, deodorant use and private vehicle use. Remarkably, a teacher candidate defines not taking action so that others would be sensitive as a negative behavior.
The subject of the research is to determine how science teacher candidates solve environmental problems. In this context, it is seen that teacher candidates form the solution of environmental problems in four sub-themes. It is stated here that besides what can be done individually, public and private institutions should take part in this process and act socially, as well as responsibilities as a teacher.

\section{Discussions}

In this section, the results of the research will be presented together with the existing literature. In 
this study, it was determined that teacher candidates often defined the environment as "the environment where living and non-living things interact," "the area where living things live," and "artificial environment-natural environment." Similar definitions are found in some studies. For example, Shepardson (2005) stated that students understood the environment as a natural place devoid of people in their drawings and explanations about the environment. Payne (1998), on the other hand, states that sixth-grade students define the environment as living and non-living things that exist naturally in the external environment, untouched by humans. Similar to this study and other studies, it is seen that students perceive the environment as "living and inanimate beings, natural environment." In the study, it is among the results that human beings affect the environment in many positive and negative ways. It is determined that teacher candidates identified air pollution as the most important problem because it affects life in every sense. Teacher candidates emphasize that air pollution is a problem as it will make breathing difficult and cause many diseases. In the studies of Jung, Mehta and Tong (2018), it is also stated that air pollution caused by vehicle exhaust gases and cigarette smoke adversely affects human health and is important.

Additionally, our teacher candidates stated that smoking caused air pollution and evaluated not smoking among their positive behaviors in their selfevaluations. In this study, air, water, soil, garbage, depletion of natural resources, destruction of nature and ozone were the most important environmental problems. When the literature is examined, it is seen that the teacher candidates have the perception that environmental pollution is caused by humans (Kalayc1, 2020). In our research, teacher candidates stated that the biggest responsible for environmental problems is human beings and the reasons like production and consumption. In similar findings, "garbage, destruction of trees, soil pollution, garbage dumping into waters, throwing waste batteries into the environment, air and sound pollution, forest fires" are seen as environmental problems (Ertürk, 2017). In another study, it was stated that water resources pollution and its effects are an important environmental problem due to serious consequences on the health and safety of communities. İt was determined that although the university students had general theoretical knowledge about industrial, agricultural and sewage water pollutants, they lacked environmental awareness about water pollution (AlMaliki et al., 2021). In our research, water pollution is the second most important environmental problem and it is stated that the decrease in water will affect food shortage and the economy.

It is demonstrated in this study that teacher candidates present solution suggestions to the environmental problems in individual, professional and managerial aspects, and they raise awareness about the environment. Cheong (2005) states in her research that teacher candidates should not only be aware of the environmental problems but also take action to solve them. In her work, she provided real environmental problems to her students and enabled them to produce and implement projects for solutions. In this context, it is seen that the suggestions of taking environmental education lessons, producing, and implementing various projects and taking part in different projects, which are included in the social solution suggestions determined by the teacher candidates, have been applied or suggested in other studies. According to the research results of Genç and Genç (2013), the significant difference in the average of knowledge and attitude towards the environment of the students who take environmental courses shows the importance of students taking courses on environment and environmental problems. Rogayan and Nebrida (2019) In a study measuring the environmental awareness level of students taking secondary school science courses in Zambales, Philippines; It is revealed that science students are very conscious of environmental concepts, the state of the environment and environmental problems, and there is a moderate relationship between their awareness of environmental consciousness. In the study of Morgil, Y1lmaz, and Cingör (2002), it was determined that because of primary school 6th-grade students doing environmental project studies and presenting them in the classroom, students became conscious about environmental education with the projects they prepared.

As a result of Kartal and Ada (2019), it was determined that the perceptions of teacher candidates 
about environmental problems are limited to not throwing garbage on the ground but sufficient about recycling. Compared to our study results, teacher candidates identified garbage as a problem. It is important for the development of environmental awareness that they mention recycling, like the collection of oils and blue caps, in their suggestions for solutions to environmental problems and their self-evaluations. Teacher candidates stated in their social solution suggestions that seminars and meetings should be held with field experts to raise awareness of society. In the studies of Karadağ and Acar (2020), it is stated that social studies teacher candidates who attend seminars, meetings, or congresses on environmental problems have a high level of awareness of environmental problems. Anılan (2014) suggested organizing social activities, panels, conferences, and seminars to inform all segments of the society, especially students and families, to solve environmental problems outside of school and to have sufficient environmental awareness. She stated that more space and time should be given to programs related to the environment in visual communication tools and importance should be given to the promotion of non-governmental organizations related to the environment. The fact that the suggestion presented as a social solution suggestion in our study creates environmental awareness in Karadağ and Acar's (2020) study makes the suggestion valuable.

According to the results of Öztürk and Öztürk (2015) research, it is seen that the participants consider the excessive use of natural resources as the most important environmental problem in the world and Turkey, and they think that the most contribution to raising awareness of the society on the environment is provided by TV and radios. As a similarity to our research, a teacher candidate states, "I would use social media. Because people of all ages are interested in social media, television and computers..." and emphasizes the importance of today's communication tools in raising awareness.

In this study, teacher candidates show that they are aware of the importance of renewable energy by including renewable energy sources among the solutions to environmental problems. Similar results are found in studies on renewable energy. For example, Yenice and Tunç (2018) found that participants' awareness of environmental problems was positive.

In this study, it is seen that teacher candidates suggest solutions to environmental problems, and they also focus on what can be done before the problem occurs. They stated that raising awareness and training from experts is important in solving problems before they occur. Aksan and Çeliker (2019) reported that the 10 -week training given to increase the waste recycling awareness of science teacher candidates in terms of sustainability increased the awareness of teacher candidates about waste and recycling. The findings of Aksan and Çeliker (2019) show that the recommendations made in our study, like raising awareness and training, can make a significant difference when implemented.

They state that it is important for people to understand and raise awareness of problems experienced in the environment before they occur with activities like drama and theater in their social solution suggestions. When we examine the managerial solution suggestions, there are opinions about the necessity of our country to give importance to international agreements and the involvement of the municipality in environmental activities. In a study, the importance of public and private sector support and the necessity of the municipality to provide a recycling environment and strict regulations were emphasized. Additionally, it is recommended to create awareness by including other extracurricular resources like social networks and online games in environmental education (Hammami, Mohammad Bakri Alaa, et al., 2017). In this study, teacher candidates made similar suggestions as "experiments, activities, visual and practical awareness-raising activities, the establishment of environmental clubs" as professional solution suggestions. Yavetz (2014) stated in their study that pre-service teachers have a mission as a teacher in their views on the environment and that they should serve as role models for their students through their environmental behaviors. Yavetz (2014) stated in her study that teacher candidates have a mission as educators in their views on the environment and that they should serve as role models for their students through their environmental behaviors.

When the results of this study and other studies are 
examined, it is recommended to raise awareness of environmental problems. For this purpose, effective environmental education should be given at all levels of education. It is important that our teachers who will give this training also receive an effective environmental education. It is recommended to take action by encouraging positive behaviors by making use of social media and technological developments of the age and to address environmental problems in social and managerial terms.

\section{Reference}

Al-Maliki, Laheab A., et al. "Perceptions about Water Pollution among University Students: A Case Study from Iraq." Cogent Engineering, vol. 8, no. 1, 2021.

Akman, Ozkan. “Teacher Candidates' Attitudes, Knowledge Levels and Sensitivities towards Environmental Problems." Journal of Education and Practice, vol. 8, no. 10, 2017.

Aksan, Zeynep, and Dilek Çelikler. "Recycling Awareness Education: Its Impact on Knowledge Levels of Science Teacher Candidates." International Electronic Journal of Environmental Education, vol. 9, no. 2, 2019, pp. 81-105.

Anilan, Burcu. "A Study of the Environmental Risk Perceptions and Environmental Awareness Levels of High School Students." Asia-Pacific Forum on Science Learning \& Teaching, vol. 15, no. 2, 2014.

Bogdan, Robert, and Sari Knopp Biklen. Qualitative Research For Education: An Introduction to Theory and Methods. Pearson, 2006.

Brody, Michael J. "Understanding of Pollution among 4th, 8th, and 11th Grade Students." The Journal of Environmental Education, vol. 22, no. 2, 1991, pp. 24-33.

Cheong, I.P-A. "Educating Pre-service Teachers for a Sustainable Environment." Asia-Pacific Journal of Teacher Education, vol. 33, no. 1, 2005, pp. 97-110.

Ertürk, Ramazan. "Environmental Problems of the Primary School Students and Perceptions for Environmental Education." Inonu University Journal of the Faculty of Education, vol. 18, no. 3,2017 , pp. 12-24
Farsakoğlu, O. Faruk, et al. "A Study on Awareness Levels of Prospective Science." World Applied Sciences Journal, vol. 4, no. 2, 200, pp. 174-182.

Genç, Murat, and Tülin Genç. "The Investigation of Candidate Teachers' Attitudes towards Environment." Asian Journal of Instruction, vol. 1, no. 1, 2013, pp. 9-19.

Hammami, Mohammad Bakri Alaa, et al. "Survey on Awareness and Attitudes of Secondary School Students Regarding Plastic Pollution: Implications for Environmental Education and Public Health in Sharjah City, UAE." Environmental Science and Pollution Research, vol. 24, 2017.

Jorgenson, Simon N., et al. "Environmental Education in Transition: A Critical Review of Recent Research on Climate Change and Energy Education." The Journal of Environmental Education, vol. 50, no. 3, 2019, pp. 160-171.

Jung, Se Ji, et al. "Effects of Environment Pollution on the Ocular Surface." The Ocular Surface, vol. 16, 2018, pp. 198-205.

Kalayci, Serpil. "Cognitive Perceptions of PreService Science Teacher for Environmental Pollution." Journal of Baltic Science Education, vol. 19, no. 3, 2020, pp. 415-428.

Karadağ, Yıldıray, and Fatih Acar. "An Analysis about Social Studies Prospective Teachers' Awareness Levels on Environmental Problems." International Journal of New Approaches in Social Studies, vol. 4, no. 1, 2020, pp. 62-78.

Kartal, Eda Erdaş, and Ezgi Ada. "Pre-school Teacher Candidates' Views about Environmental Problems and Recycling." YYU Journal of Education Faculty, vol. 16, no. 1, 2019, pp. 818-847.

Kim, Sung Eun, et al. "Environmental Degradation and Public Opinion: The Case of Air Pollution in Vietnam." The Journal of Environment \& Development, vol. 29, no. 2, 2020, pp. 196222.

Lloyd-Strovas, Jenny, et al. "Environmental Literacy of Undergraduate College Students: Development of the Environmental Literacy 
Instrument (ELI)." School Science and Mathematics, vol. 118, 2018, pp. 84-92.

Marton, Ference, and Shirley Booth. Learning and Awareness. Routledge, 1997.

Özdemir, Oğuz. “A New Environmental Education Perspective: Education for Sustainable Development." Education and Science, vol. 32, 2010, pp. 23-38.

Öztürk, Talip, and Filiz Zayimoğlu Öztürk. "Opinions of Pre-Service Teachers about Environment and Environmental Education Ordu University Sample." Ballkesir University The Journal of Social Sciences Institute, vol. 18, 2015, pp. 115-132.

Payne, Phillip. "Children's Conceptions of Nature." Australian Journal of Environmental Education, vol. 14, 1998, pp. 19-26.

Rogayan, Danilo V., and Eveyen El Elyonna D. Nebrıda. "Environmental Awareness and Practices of Science Students: Input for Ecological Management Plan.” International Electronic Journal of Environmental Education, vol. 9, no. 2, 2019, pp. 106-119.

Shepardson, Daniel P. "Student Ideas: What is an Environment?" Journal of Environmental Education, vol. 36, no. 4, 2005.

Soares, Joana, et al. "Public Views on Plastic Pollution: Knowledge, Perceived Impacts, and Pro-Environmental Behaviours." Journal of Hazardous Materials, vol. 412, 2021.

Toomey, Anne H., and Margret C. Domroese. "Can Citizen Science Lead to Positive Conservation Attitudes and Behaviors?." Human Ecology Review, vol. 20, no. 1, 2013, pp. 50-62.

Yavetz, Bela, et al. "How do Preservice Teachers Perceive 'Environment' and its Relevance to their Area of Teaching?." Environmental Education Research, vol. 20, no. 3, 2014, pp. 354-371.

Yenice, Nilgün, and Gizem Alpak Tunç. "An Analysis of Pre-Service Science Teachers' Attitude towards Renewable Energy Sources and Their Awareness towards Environmental Problems." Uludağ Üniversitesi Ĕ̆itim Fakültesi Dergisi, vol. 31, no. 1, 2018, pp. 207-222.

Yıldırım, Ali, and Hasan Şimşek. Sosyal Bilimlerde Nitel Araştırma Yöntemleri. Seçkin Yayınc1lık, 2013.

Yoloğlu, Ali Cenap, and Bülent Halisdemir. "An Empirical Study on Environmental Awareness and Environmental Attitudes of University Students: The Case of Mersin University." The Journal of Academic Social Science, vol. 8, 2020, pp. 91-107

\section{Author Details}

Asiye Berber, Assistant Professor, Faculty of Education, Eskişehir Osmangazi University, Eskişehir, Turkey, EmailID: aberber@ogu.edu.tr. 